鰐㴊 昌彦1), 平野 透 ${ }^{2)}$, 秋山 幸功 ${ }^{1)}$, 三國 信啓 ${ }^{1)}$

1）札幌医科大学医学部脳神経外科，2）札幌医科大学附属病院放射線部

\title{
Fusion Images for Endonasal Transsphenoidal Surgery
}

\author{
Masahiko Wanibuchi, M.D., Ph.D. ${ }^{1)}$, Toru Hirano, R.T., M.S. ${ }^{2)}$, Yukinori Akiyama, M.D., Ph.D. ${ }^{1)}$, \\ and Nobuhiro Mikuni, M.D., Ph.D. ${ }^{1)}$ \\ 1) Department of Neurosurgery, Sapporo Medical University School of Medicine, 2) Division of Radiology, Sapporo Medical Univer- \\ sity Hospital
}

In endoscopic endonasal transsphenoidal surgery, it is essential to determine the precise anatomical relationship of the sellar or parasellar tumor with the internal carotid artery and the optic nerve prior to surgery in order to preserve the important structures and to avoid surgical complications. Computed tomography (CT) using a 64detector row scanner and magnetic resonance imaging (MRI) using a 3.0 tesla system were used to create CT/ MRI fusion images. Three orthogonal multiplanar reconstruction images including volume rendering (VR) and virtual endoscopy (VE) were created using a work station by radiological technologists in a 3-dimensional laboratory established in our hospital. The fusion images were then uploaded to a picture archiving communication system (PACS).

When using system, the anatomical relationship between tumors and adjacent structures was clearly demonstrated. Additionally, the VR and VE images allow surgeons to make precise presurgical plans and conduct virtual operations. Furthermore, because the images can be observed anytime on PACS in the hospital, CT/MRI fusion images in endonasal transsphenoidal surgery contribute as very useful tools not only for the education of trainees and medical students but also for obtaining informed consent from patients and their families.

(Received September 5, 2014; accepted October 6, 2014)

Key words : fusion image, virtual reality, endonasal transsphenoidal surgery, neuroendoscopy Jpn J Neurosurg（Tokyo）24:92-98, 2015

\section{はじめに}

近年，経鼻経蝶形骨洞手術は顕微鏡から神経内視鏡を 主とした手術へと変貌し，トルコ鞍病変のみならず，鞍 上部，海綿静脈洞などの傍鞍部，さらには前頭蓋底や斜 台部, 脳幹腹側病変へと適応が拡大されてきている ${ }^{4) 10)}$. 内視鏡では顕微鏡よりも広い視野角が得られるのが特徵 で，より外側まで観察可能となっている。一方，全体的 に広がったように見元, 視点により病変と周辺構造物の
解剖学的位置関係が相対的に変化するため, 内視鏡の視 野角に合わせた画像を術前から把握することは重要であ る. 当院では computed tomography (CT), magnetic resonance imaging（MRI）おのおのの利点を活かす CT/MRI fusion 画像をルーチンに作成しており，手術計画の立案 に応用している，実際に作成している 3-dimensional（3 D) virtual reality 画像を紹介するとともに，その有用性に つき考察する。 

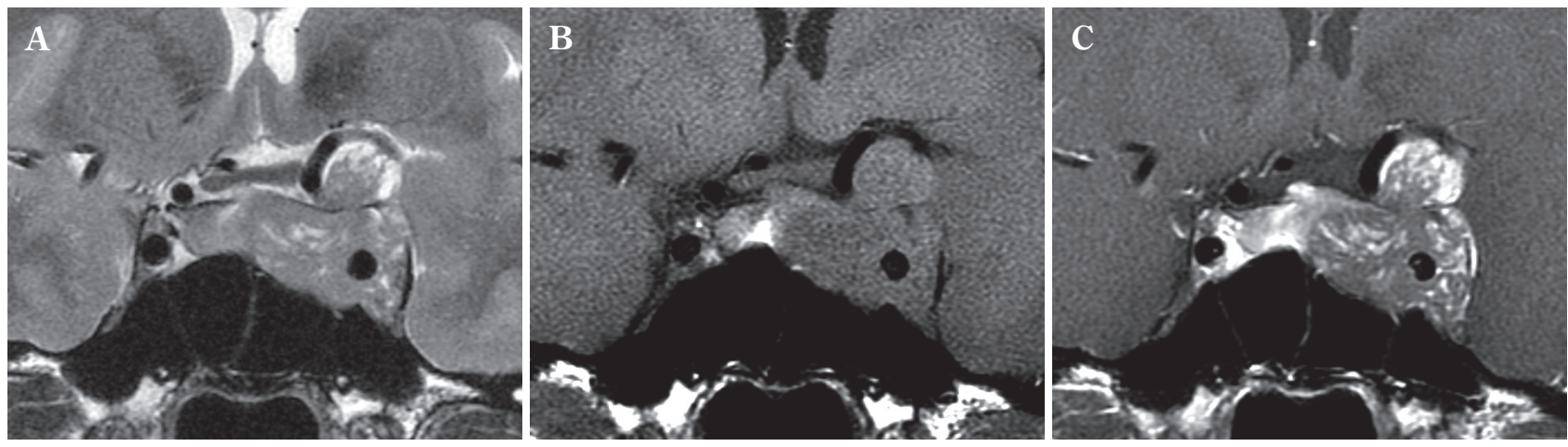

Fig. 1 Representative case of pituitary adenoma

Coronal view of $\mathrm{T}^{-}-(\mathbf{A}), \mathrm{T}^{-}-(\mathbf{B})$, and contrast enhanced T1-weighted images (C) demonstrated a pituitary adenoma extending toward the intradural space through the cavernous sinus.

\section{方 法}

CT は 64 列 の Light speed VCT Vision (GE healthcare, Princeton, NJ, USA）を使用している。 ス ライス厚は $0.625 \mathrm{~mm}$, 再構成間隔 $0.312 \mathrm{~mm}$, helical pitch 0.531 で，FOV は鼻を含めて再構成している. MRI は Signa HDX 3 T（GE healthcare）を使用し，脳神経描 出のために fast imaging employing steady state acquisition (FIESTA)-C を $0.4 \mathrm{~mm}$ 厚で撮影している. Fusion は Ziostation 2（アミン株式会社, 東京) というワークス テーションを使用している.

Registration は axial, coronal, sagittal の 3 断面で S 状 静脈洞, 脳底動脈, 中大脳動脈, 内頝動脈, 蝶形骨洞, 内耳道，第四脳室，斜台を手動で合わせている，CT か らは骨, 腫瘍, 動脈, 静脈を, MRI からは脳や下垂体を 抽出している。脳神経は FIESTA-C で同定し, ワークス テーションのパス計測ツールのうち, PATH を使用して 自動トレース後, 手動で削り出しを行っている。画像は volume rendering (VR) と virtual endoscopy (VE) mode の 2 種類を使用しており, VR では縦や横方向の回転に 加え, 術野と同一方向からの観察像を, VE では内視鏡 の視野角に一致させアプローチに合わせた画像を作成し ている.

\section{結 果}

2013 年 12 月までに下垂体腺腫 42 例，春索腫 10 例， 頭蓋咽頭腫 5 例, 髄膜腫 3 例, その他 11 例, 合計 71 例 の経鼻経蝶形骨洞手術に対してこれらの fusion 画像を 作成した。海綿静脈洞から硬膜内へ進展した下垂体腺腫 の症例を提示する（Fig. 1).

\section{1 鼻腔内の画像}

経鼻手術では両側の鼻腔から蝶形骨洞に至るまで，鼻 粘膜と vomer bone を外した正中からのアプローチや, 鼻粘膜を残し自然孔経由で蝶形骨洞内へ到達するアプ ローチを VE 画像で再現している（Fig. 2)．鼻腔内の情 報として，下鼻甲介，中鼻甲介，上鼻甲介，自然孔など 手術で指標となる構造物は描出可能であった。鼻甲介の 大きさ，鼻中隔の弯曲程度も術野イメージで確認でき， アプローチする空間の広さを視覚的に捉えることが可能 であった。

\section{2 蝶形骨洞内の画像}

蝶形骨洞内も VE 画像で再現している。0 度の内視鏡 を想定した正中から正面の view に加え，先端が 30 度の 内視鏡を使用することも考慮し，左右におのおの 30 度 傾けた view も作成している。また，骨透過画像を追加 し，骨表面からの view のみならず，骨指標と硬膜内構 造物の関係も確認している（Fig. 3).

\section{3 硬膜内の画像}

硬膜内はVR, VE 両者で画像化している。VR 画像で は，腫瘍，脳神経，下垂体，内頝動脈，後交通動脈，前 大脳動脈，海綿静脈洞の位置関係が明瞭に認識でき，手 術野では病変の裹側に隠れる構造物も立体的に把握可能 であった（Fig. 4)。視神経，視交叉，視索は基本的に描 出可能であったが，視力の悪い症例では菲薄化した視神 経が描出できない症例も存在した。また，脳槽部の動眼 神経や外転神経は描出可能であったが，海綿静脈洞部で 腫瘍に圧排された部分は把握が困難であった。

VE 画像では，腫瘍と周辺構造物の関係が，術野と同 様のイメージで理解できた（Fig. 5)。特に内視鏡では視 

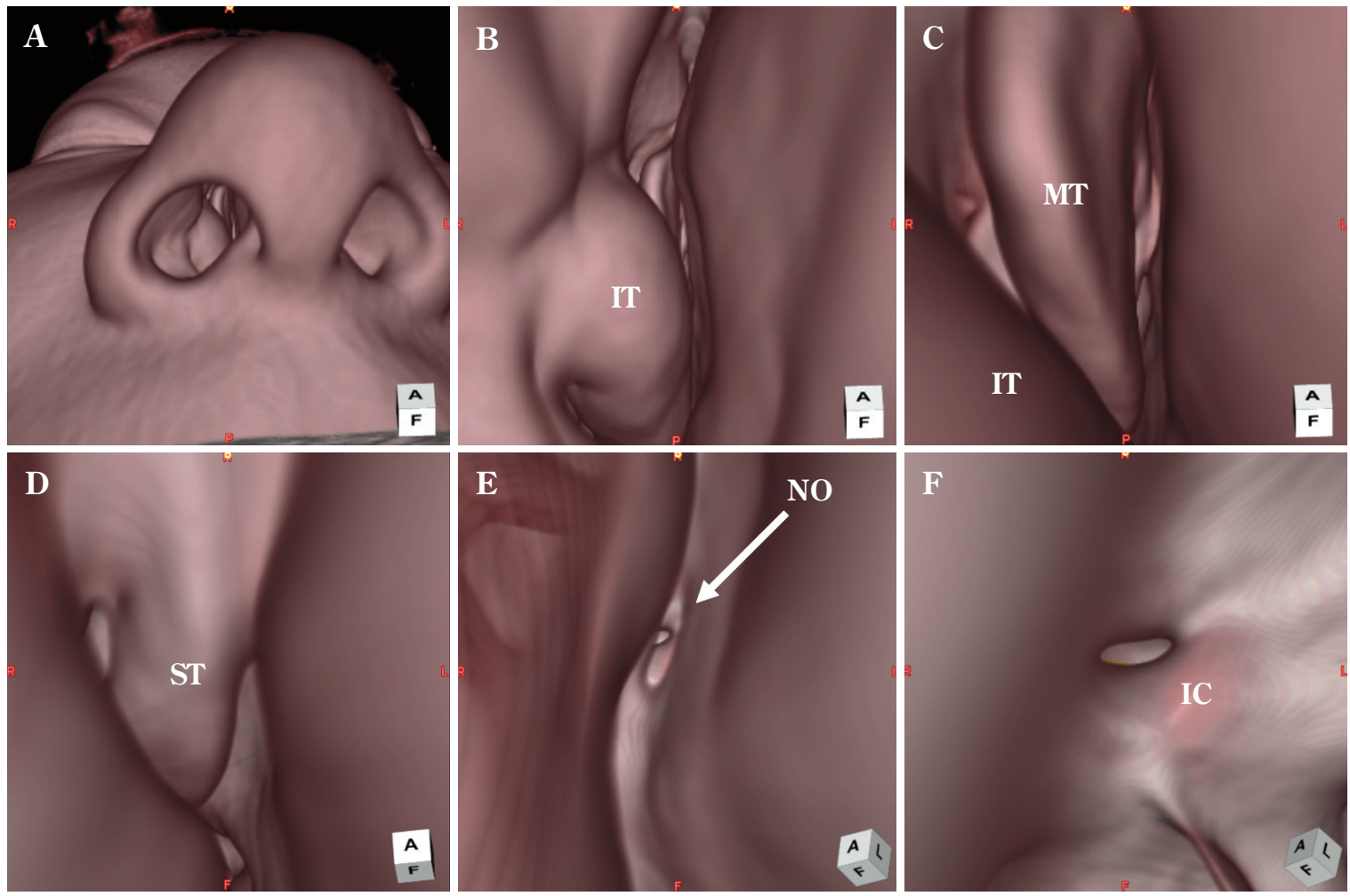

Fig. 2 Virtual endoscopy in the nasal cavity

An approach through the right nasal cavity was virtually reproduced. The nasal nostril (A), the inferior turbinate (IT, B), the middle turbinate (MT, C), the superior turbinate (ST, D), and the natural ostium (NO) of the sphenoid sinus (E) were observed. The C3 portion of the right internal carotid artery (IC, F) was seen through the bony protrusion.
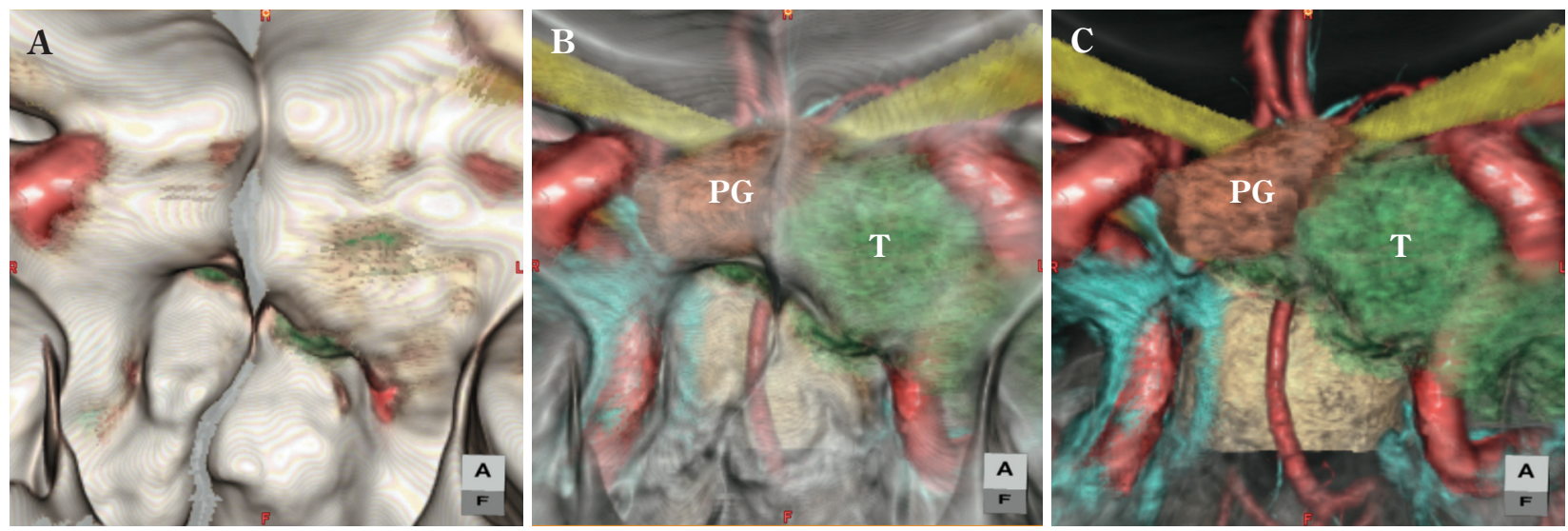

Fig. 3 Virtual endoscopy in the sphenoid sinus

The changing opacity of the bony structure allowed significant visualization of the relationship between the sella floor and the intradural structures.

$\mathrm{PG}$ : pituitary gland, $\mathrm{T}:$ tumor

野周辺の構造物が広がってみえるのが特徴で，VR のみ ではイメージしにくかったが，VEではこの効果が忠実 に再現されるため, 内頝動脈外側での動眼神経の走行な ぞは良好に把握可能であった（Fig. 5D）。

\section{考察}

経鼻経蝶形骨洞手術における CT/MRI fusion 画像は 手術所見と良好に一致していた。画像融合の技術は研究 

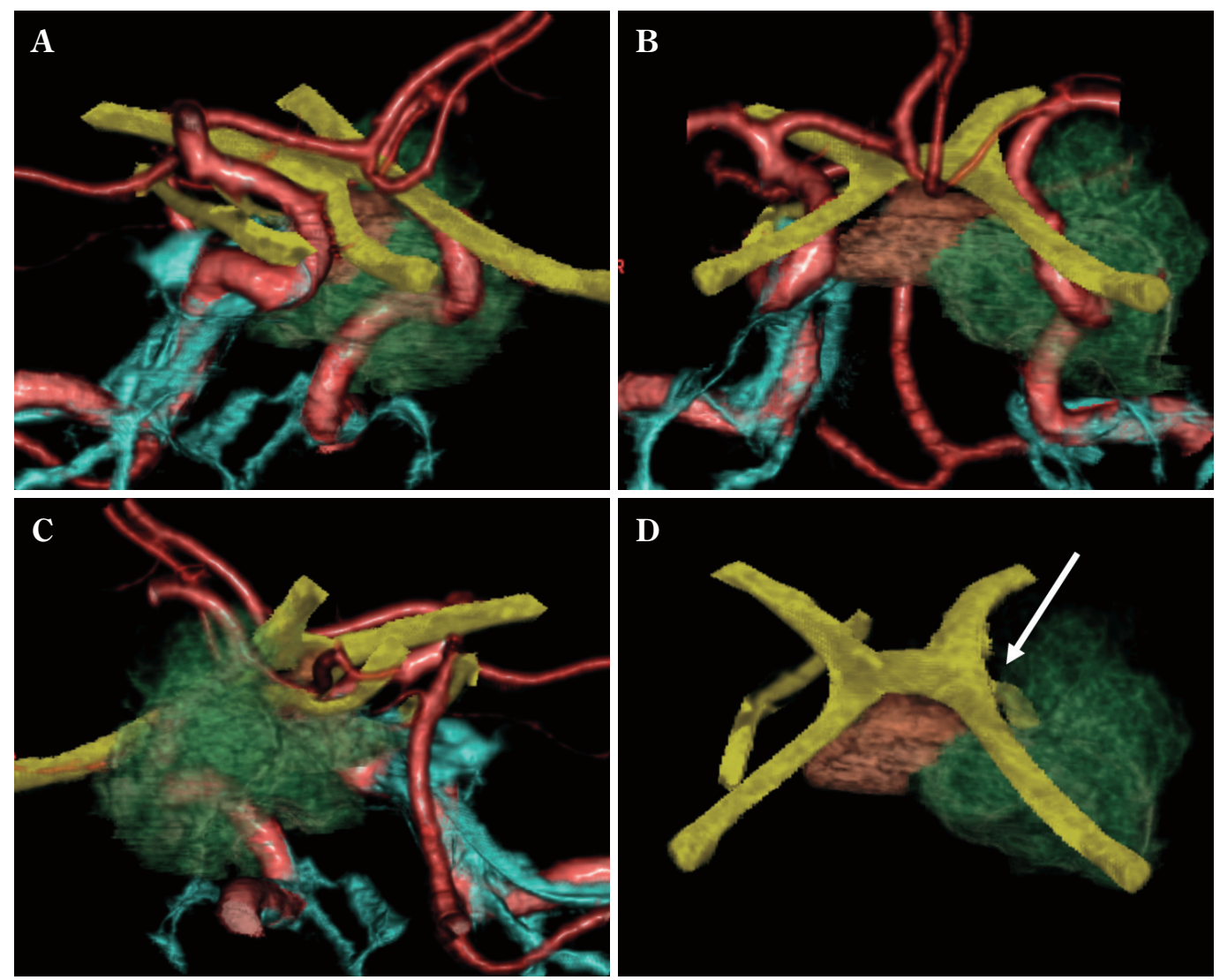

Fig. 4 Volume rendering of the tumor and adjacent structures

Volume rendering of the tumor and related structures was also performed to observe the relationship between each structure. The optic nerve, the oculomotor nerve, the internal carotid artery, the cavernous sinus, the pituitary gland, and the tumor were clearly demonstrated from all directions (A : from a superior-lateral view on the right side, B : from an anterio-superior view, $\mathbf{C}$ : from a posterior-lateral view on the left side). $\mathbf{D}:$ The cisternal segment of the oculomotor nerve on the left side compressed medially by the tumor was also confirmed. However, it was difficult to distinguish the cavernous portion of the oculomotor nerve.

分野から日常診療のルーチンワークへ応用されるように なり，位置情報を持ったデジタルデータ同士であれば, 精度を担保しながら fusion することが可能となってき た ${ }^{14) 15)}$.アナログデータをデジタルデータに変換して三 次元構築を行っていた時代から, 現在はデジタルデータ をそのまま三次元化できるようになり，画像処理の速度 が飛躍的に向上している ${ }^{3)}$. 脳神経外科領域では 1990 年 前後より頭蓋底領域の CT/MRI fusion image が報告さ れ, 脳腫瘍や頭蓋底病変, 微小神経血管減圧術, 深部脳 刺激療法の評価などに使用されている778)12)13)16)19) 21). ほかの領域では乳癌評価での MRI/echo の fusion が, 骨 盤病変では MRI 同士の T2 強調画像/拡散強調画像の fusion，転移巣の検索では PET/CT or MRI の fusion，心 筋の評価では SPECT/CT や MRI の fusion ${ }^{2)}$ が使用され ている ${ }^{11) 17) 18)}$ 。これらは構造同士の fusion と機能画像の fusion の 2 種類に大別され，今回紹介した方法は構造の 可視化といえる.

CT と MRI の fusion 画像ではおのおのの利点を活か すことができ, 鼻腔内のアプローチ, 蝶形骨洞内の観察, 硬膜内操作をするうえでは VE 画像が有用であった。内 視鏡は 80 度の範囲を同一視野に捉えることができるた め，視点を対象物へ近づけることにより絶対的位置関係 は不変であるにもかかわらず，相対的位置関係が異なっ て観察される。このような遠近感の強調効果をもたらす VE 画像は, 術者が行う仮想手術を視覚情報として具現 化することができた。一方，VR 画像ではあらゆる方向 から観察可能であり, 実際の手術野ではみえない部分も 把握することができるため, 手術計画の立案, 重要構造 物の温存, ならびに危険回避という点で有用であった. また，これらの VE や VR 画像は術者のみならず，患者 

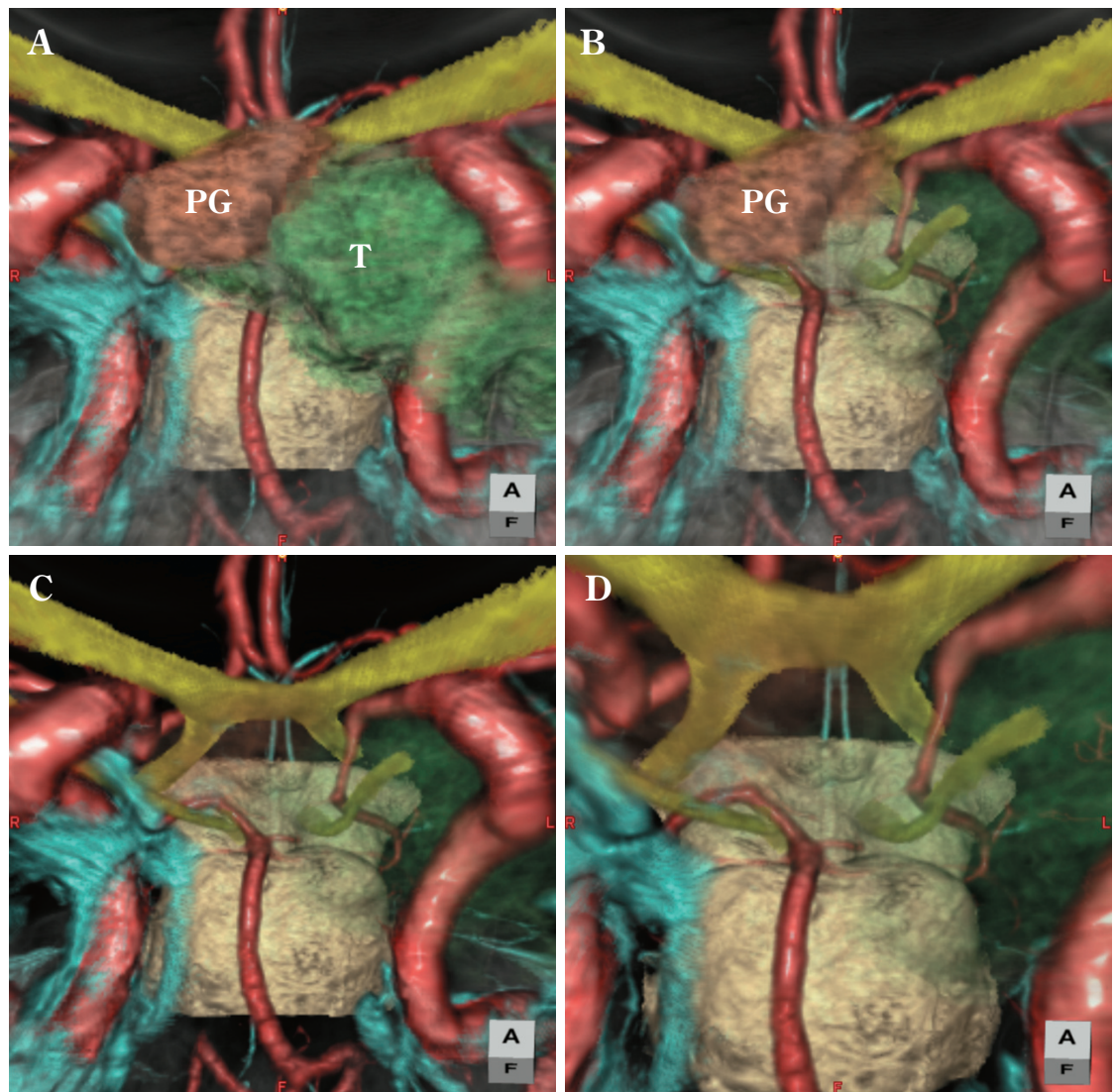

Fig. 5 Virtual endoscopy inside the dura

Structures related to the surgery were confirmed by virtual endoscopy mode. The tumor extended to the left cavernous sinus encasing the internal carotid artery (A). The location of the posterior communicating artery and the cisternal segment of the oculomotor nerve were demonstrated by increasing the transparency of the tumor (B). The chiasm, the optic tracts, and the mammillary bodies were verified after the pituitary gland was lucent (C). The relative appearance of each anatomical structure was altered as the view point approached (D).

$\mathrm{PG}:$ pituitary gland, $\mathrm{T}:$ tumor

や若手医師，医学部生にとっても有用であると考えられ た．患者とその家族に対して病状説明する際には，色分 けされた静止画と動画は非常に印象的であり，腫瘍の近 傍に重要な血管や神経が走行していることを容易に把握 可能で，病状や手術方法を理解してもらう場面で助力と なった，同様のことは研修医や若手医師，医学部生に対 しても当てはまり, 医学教育という点でも有用であった。 当院では 2008 年に画像処理部門である 3D ラボが併 設され，専門的知識を持った放射線部の診療放射線技師 が 3D fusion 画像を作成している. 20 年前はデー夕移動 だけで 1 時間, CT と MRI を fusion させるために 6.5 時 間かかると報告されていた ${ }^{6)}$. 当院では single helical CT の時代から fusion 画像の作成を試みており, 現在では registration にかかる時間は約 5 分, 神経描出は一つの神
経につき数分, 動静脈の分離に 60 分, 後処理に 30 分, 全体で約 120 分を要している。術野のイメージに近づけ るためには自動的な縦や横方向の回転のみではなく，手 術を理解したうえで手動で brush up を行うことが重要 と考元られた。3D ラボでは日中の勤務時間内に画像処 理を行える環境が整っており，脳神経外科領域では下垂 体近傍病変のみならず，手術を行う患者すべてに同様の 処理を行っている．当院では日常臨床の一環として網羅 的に画像処理を行っており，特別に指定しなくても疾患 と部位からアプローチを考慮した適切な画像が画像閲覧 システムに upload されるため, 院内の端末であればどこ からでも画像をみることができる。また，このような画 像は頭䅡部領域以外でも行われており，神経チームは 5 人，全領域となると 20 人以上が携わっている，実用的 
画像を作るには解剖学的知識と, 画像処理に習熟する必 要があるが, fusion 画像を作成し始めてから $1 \sim 2$ 年で完 成度の高い画像が得られるようになる。

Fusion 画像をシームレスに作成するには，普段からの 放射線技師と医師との連携が重要である。当院では週に 1 回, 神経放射線カンファレンスを, 月に 1 回, 3D 画像 カンファレンスを開き, 術前画像と術中所見を比較検討 し, 必要に応じて改善を加えている. 毎月のカンファレ ンスには院内のみではなく, 近隣の病院で脳神経外科領 域の画像に携わっている診療放射線技師も多数参加し, 画像の brush up を図っており, 近年では医療分野におけ るこのような医師-技師の相互関係の重要性が強調され てきている ${ }^{5) 9}$. 定期的カンファレンスにより, 医師に とっては術者としての視点を理解してもらうことがで き, 何をどのように読影しているか, 何を重要と考えて いるかを技師側へ伝えることができ，逆に技師にとって は自分たちの作成した画像が手術でどのように役立って いるかを実感し, 解剖を基礎とした手術の理解が進むと いう点で互いに利点があると考えられた。

しかし，構造物がすべて画像化できるわけではなく， 腫瘍により著明に圧迫されて菲薄化した神経は描出する ことはできなかったので, 今後は神経線維の描出法や時 間軸を考慮した画像, tactile feedback が得られる module を追加するなど, より一層手術に近づけるようさら に発展, 改善していく必要があると考えられる11. また, 現ワークステーションでは 8 種類のパーツまでしか fusion できないため, この数を増やすことも重要な課題 と考えられた。

\section{結 語}

経鼻頭蓋底手術における fusion 画像は，手術はもちろ んのこと, 病状説明, 医学教育という面でも有用であっ た。画像作成にあたっては, 脳神経外科医と放射線技師 の連携・信頼関係構築が必要で, 互いが協力して精度の 高い臨床に即した画像を作成することが重要と考元られ た.

著者の COI (conflicts of interest) 開示: 本論文の発表に 関して開示すべきCOI はありません。

\section{文 献}

1) Alaraj A, Charbel FT, Birk D, Tobin M, Luciano C, Banerjee PP, Rizzi S, Sorenson J, Foley K, Slavin K, Roitberg $\mathrm{B}$ : Role of cranial and spinal virtual and augmented reality simulation using immersive touch modules in neurosurgi- cal training. Neurosurgery 72 Suppl 1: 115-123, 2013.

2) Bisplinghoff S, Hänisch C, Becker M, Radermacher K, de la Fuente $\mathrm{M}$ : Fusion of coronary angiography and stress echocardiography for myocardial viability evaluation. Int $J$ Comput Assist Radiol Surg 2014. [Epub ahead of print]

3) Boxwala AA, Rosenman JG: Retrospective reconstruction of three-dimensional radiotherapy treatment plans of the thorax from two dimensional planning data. Int J Radiat Oncol Biol Phys 28: 1009-1015, 1994.

4) Cavallo LM, Prevedello DM, Solari D, Gardner PA, Esposito F, Snyderman CH, Carrau RL, Kassam AB, Cappabianca P: Extended endoscopic endonasal transsphenoidal approach for residual or recurrent craniopharyngiomas. $J$ Neurosurg 111: 578-589, 2009.

5) Duijm LE, Groenewoud JH, Fracheboud J, de Koning HJ : Additional double reading of screening mammograms by radiologic technologists: impact on screening performance parameters. J Natl Cancer Inst 99: 1162-1170, 2007.

6) Gandhe AJ, Hill DL, Studholme C, Hawkes DJ, Ruff CF, Cox TC, Gleeson MJ, Strong AJ: Combined and threedimensional rendered multimodal data for planning cranial base surgery: a prospective evaluation. Neurosurgery 35: 463-470; discussion 471, 1994.

7) González Sánchez JJ, Enseñat Nora J, Candela Canto S, Rumiá Arboix J, Caral Pons LA, Oliver D, Ferrer Rodrigues E: New stereoscopic virtual reality system application to cranial nerve microvascular decompression. Acta Neurochir (Wien) 152: 355-360, 2010.

8) Hill DL, Hawkes DJ, Hussain Z, Green SE, Ruff CF, Robinson GP: Accurate combination of CT and MR data of the head: validation and applications in surgical and therapy planning. Comput Med Imaging Graph 17:357-363, 1993.

9）岩谷良則：21 世紀の医療の要：臨床検査技師：その課題 と展望。臨床病理 56：915-923，2008。

10) Kassam AB, Prevedello DM, Carrau RL, Snyderman CH, Thomas A, Gardner P, Zanation A, Duz B, Stefko ST, Byers K, Horowitz MB: Endoscopic endonasal skull base surgery: analysis of complications in the authors' initial 800 patients. J Neurosurg 114: 1544-1568, 2011.

11) Kim SK, Choi HJ, Park SY, Lee HY, Seo SS, Yoo CW, Jung DC, Kang S, Cho KS : Additional value of MR/PET fusion compared with PET/CT in the detection of lymph node metastases in cervical cancer patients. Eur J Cancer 45 : 2103-2109, 2009.

12) Kin T, Nakatomi H, Shojima M, Tanaka M, Ino K, Mori H, Kunimatsu A, Oyama H, Saito N: A new strategic neurosurgical planning tool for brainstem cavernous malformations using interactive computer graphics with multimodal fusion images. J Neurosurg 117: 78-88, 2012.

13) Kin $T$, Shin M, Oyama H, Kamada K, Kunimatsu A, Momose T, Saito N: Impact of multiorgan fusion imaging and interactive 3-dimensional visualization for intraventricular neuroendoscopic surgery. Neurosurgery 69 (1 Suppl Operative) : ons40-48; discussion ons48, 2011.

14) Leong JL, Batra PS, Citardi MJ : CT-MR image fusion for the management of skull base lesions. Otolaryngol Head Neck Surg 134: 868-876, 2006.

15) Li G, Xie H, Ning H, Citrin D, Capala J, Maass-Moreno R, Guion P, Arora B, Coleman N, Camphausen K, Miller $\mathrm{RW}$ : Accuracy of $3 \mathrm{D}$ volumetric image registration based 
on CT, MR and PET/CT phantom experiments. $J$ Appl Clin Med Phys 9:2781, 2008.

16) Mukherji SK, Rosenman JG, Soltys M, Boxwala A, Castillo M, Carrasco V, Pizer SM: A new technique for CT/ MR fusion for skull base imaging. Skull Base Surg 6: 141-146, 1996.

17) Nakano S, Yoshida M, Fujii K, Yorozuya K, Mouri Y, Kousaka J, Fukutomi T, Kimura J, Ishiguchi T, Ohno K, Mizumoto T, Harao M: Fusion of MRI and sonography image for breast cancer evaluation using real-time virtual sonography with magnetic navigation: first experience. Jpn J Clin Oncol 39: 552-559, 2009.

18) Nishie A, Stolpen AH, Obuchi M, Kuehn DM, Dagit A, Andresen $\mathrm{K}$ : Evaluation of locally recurrent pelvic malignancy: performance of T2- and diffusion-weighted MRI with image fusion. J Magn Reson Imaging 28:705-713,
2008.

19) O'Gorman RL, Jarosz JM, Samuel M, Clough C, Selway RP, Ashkan K : CT/MR image fusion in the postoperative assessment of electrodes implanted for deep brain stimulation. Stereotact Funct Neurosurg 87:205-210, 2009.

20) Oishi M, Fukuda M, Ishida G, Saito A, Hiraishi T, Fujii Y : Presurgical simulation with advanced 3-dimensional multifusion volumetric imaging in patients with skull base tumors. Neurosurgery 68 (1 Suppl Operative) : 188-199; discussion 199, 2011.

21) Pelizzari CA, Chen GT, Spelbring DR, Weichselbaum RR, Chen CT: Accurate three-dimensional registration of CT, PET, and/or MR images of the brain. J Comput Assist Tomogr 13:20-26, 1989.

\section{経鼻経蝶形骨洞手術における fusion 画像}

\section{鮕㴊 昌彦 平野 透 秋山 幸功 三國 信啓}

経鼻経蝶形骨洞手術では, 重要構造物を温存し, 合併症を回避するために, 鞍部・傍鞍部腫瘍と内 頝動脈や視神経などの解剖学的関係を詳細に把握する必要がある. 当院ではこれらの腫瘍に対して, computed tomography (CT) と magnetic resonance imaging (MRI) を使用し, 互いの画像を fusion している. 画像は院内併設の画像処理部門である 3D ラボで, 専門的知識を持った放射線部の診療放 射線技師が作成し, volume rendering (VR) と virtual endoscopy (VE) 画像を画像配信システム (PACS) へ upload している. CT/MRI fusion 画像により, 腫瘍と周囲の解剖構造物の関係が明瞭に同定され, VR, VE 画像は手術計画の立案や仮想手術を行ううえで有用であった. また, fusion 画像はどの PACS からでも閲覧可能なので，患者への病状説明や医学教育という面でも有用であった. 